$4 \mathrm{mg}$ on background MTX. At 24 wks, csDMARD-IR pts receiving placebo (PBO) were switched to $4 \mathrm{mg}$ on background csDMARD. Radiographs at baseline, year 1 and year 2 were scored using the van der Heijde modified total sharp score (mTSS). Data are least squares mean change from baseline using mixed model repeated measures on observed data.

Results: Of all pts randomised, $82.5 \%$ entered the LTE, and $87.6 \%$ of those could be entered in this analysis. At year 2, progression was significantly lower with initial bari (including monotherapy) vs. initial MTX in DMARD-naïve pts. In MTX/csDMARD-IR pts, progression with initial bari was significantly lower than initial PBO, and similar to initial ADA.

\begin{tabular}{|c|c|c|c|c|c|c|}
\hline \multirow[b]{2}{*}{ DMARD-naïve } & \multicolumn{3}{|c|}{1 year (52 weeks) } & \multicolumn{3}{|c|}{2 years (100 weeks) } \\
\hline & $\begin{array}{c}M T X \\
N=136\end{array}$ & $\begin{array}{c}\text { Bari } 4 \mathrm{mg} \\
\text { mono } \\
\mathrm{N}=120\end{array}$ & $\begin{array}{c}\text { Bari } 4 \mathrm{mg} \\
+\mathrm{MTX} \\
\mathrm{N}=150\end{array}$ & $\begin{array}{c}\mathrm{MTX} \rightarrow \\
\text { Bari } 4 \mathrm{mg} \\
\mathrm{mono}^{+} \\
\mathrm{N}=136\end{array}$ & $\begin{array}{c}\text { Bari } 4 \mathrm{mg} \\
\text { mono } \\
\mathrm{N}=117\end{array}$ & $\begin{array}{c}\text { Bari } 4 \mathrm{mg} \\
+\mathrm{MTX} \rightarrow \\
\text { Bari } 4 \mathrm{mg} \\
\text { mono }^{+} \\
\mathrm{N}=150\end{array}$ \\
\hline Change in $(\Delta) \mathrm{mTSS}$ & 1.62 & 1.14 & $0.37^{\star \star \star}$ & 1.97 & 1.35 & $0.61^{\text {**ネ}}$ \\
\hline $\begin{array}{l}\Delta \mathrm{mTSS} \leq 0.5 \\
\mathrm{n}(\%)\end{array}$ & $85(63)$ & $89(74)^{*}$ & $126(84)^{\star \star \star \star}$ & $77(57)$ & $83(71)^{*}$ & $120(80)^{\star \star \star \star x}$ \\
\hline & \multicolumn{3}{|c|}{1 year (52 weeks) } & \multicolumn{3}{|c|}{2 years ( 100 weeks) } \\
\hline MTX-IR & $\begin{array}{c}\mathrm{PBO} \rightarrow \\
\text { Bari } 4 \mathrm{mg} \\
\mathrm{N}=358\end{array}$ & $\begin{array}{c}\text { Bari } 4 \mathrm{mg} \\
\mathrm{N}=380\end{array}$ & $\begin{array}{c}\mathrm{ADA}^{ \pm} \\
\mathrm{N}=260\end{array}$ & $\begin{array}{c}\mathrm{PBO} \rightarrow \\
\text { Bari } 4 \mathrm{mg}^{\mathrm{s}} \\
\mathrm{N}=357\end{array}$ & $\begin{array}{c}\text { Bari } 4 \mathrm{mg} \\
\mathrm{N}=376\end{array}$ & $\begin{array}{c}\mathrm{ADA} \rightarrow \\
\text { Bari } 4 \mathrm{mg} \\
\mathrm{N}=260\end{array}$ \\
\hline$\Delta \mathrm{mTSS}$ & 1.64 & $0.81^{\star \star \star x}$ & $0.81^{\star \star}$ & 2.20 & $1.13^{\star x \pi}$ & $1.14^{* \star}$ \\
\hline $\begin{array}{l}\Delta \mathrm{mTSS} \leq 0.5 \\
\mathrm{n}(\%)\end{array}$ & $228(64)$ & $287(76)^{\star \star \star *}$ & $196(75)^{\star \star}$ & $212(59)$ & $269(72)^{\star \star \star}$ & $190(73)^{* * n}$ \\
\hline & \multicolumn{3}{|c|}{1 year (48 weeks) } & \multicolumn{3}{|c|}{2 years ( 96 weeks) } \\
\hline csDMARD-IR & $\begin{array}{c}\mathrm{PBO} \rightarrow \\
\text { Bari } 4 \mathrm{mg} \\
\mathrm{N}=143\end{array}$ & $\begin{array}{c}\text { Bari } 2 \mathrm{mg} \\
\mathrm{N}=157\end{array}$ & $\begin{array}{c}\text { Bari } 4 \mathrm{mg} \\
\mathrm{N}=144\end{array}$ & $\begin{array}{c}\mathrm{PBO} \rightarrow \\
\text { Bari } 4 \mathrm{mg} \\
\mathrm{N}=153\end{array}$ & $\begin{array}{c}\text { Bari } 2 \mathrm{mg} \\
\mathrm{N}=163\end{array}$ & $\begin{array}{c}\text { Bari } 4 \mathrm{mg} \\
\mathrm{N}=149\end{array}$ \\
\hline$\Delta \mathrm{mTSS}$ & 1.09 & 0.70 & $0.44^{\star}$ & 1.42 & 0.98 & $0.68^{\star}$ \\
\hline $\begin{array}{l}\Delta \mathrm{mTSS} \leq 0.5, \\
\mathrm{n}(\%)\end{array}$ & $104(73)$ & $125(80)$ & $120(83)^{*}$ & $105(69)$ & $119(73)$ & $122(82)^{\star \star \star}$ \\
\hline
\end{tabular}

Missing scores at 2 years were imputed using linear extrapolation based on data collected between 1 and 2 years; Time point=time from randomisation in originator study, $\mathrm{N}=$ number of pts with non-missing baseline and non-missing postbaseline mTSS data.

tPts switched to bari $4 \mathrm{mg}$ at entry to LTE (at Week 52).

"Pts switched to bari $4 \mathrm{mg}$ at rescue or at Week 24.

tPts switched to bari $4 \mathrm{mg}$ at rescue or at entry to LTE (at Week 52 ).

SPts switched to bari $4 \mathrm{mg}$ at rescue or at entry to LTE (at Week 24). Comparisons analysed using MMRM. ${ }^{\star} p \leq 0.05,{ }^{\star \star} p \leq 0.01,{ }^{\star \star \star} p \leq 0.001 v s$. PBO or MTX.

Conclusions: Treatment with once-daily oral bari resulted in low rates of radiographic progression for up to 2 years. Pts starting with bari showed progression that was significantly less than those starting with PBO or MTX, and comparable to those starting with ADA. The most robust benefit was seen with the $4 \mathrm{mg}$ dose.

Disclosure of Interest: D. van der Heijde Consultant for: AbbVie, Amgen, Astellas, AstraZeneca, BMS, Boeringer Ingelheim, Celgene, Daiichi Sankyo, Eli Lilly and Company, Galapagos, Gilead, Janssen, Merck, Novartis, Pfizer, Regeneron, Roche, Sanofi-Aventis, UCB, Employee of: Director of Imaging Rheumatology bv, M. Schiff Consultant for: Abbvie, BMS, Eli Lilly and Company, Johnson \& Johnson, Speakers bureau: Abbvie, Y. Tanaka Grant/research support from: Mitsubishi-Tanabe, Takeda, Daiichi-Sankyo, Chugai, BMS, MSD, Astellas, Abbvie, Eisai, Speakers bureau: Abbvie, Chugai, Daiichi-Sankyo, BMS, Mitsubishi-Tanabe, Astellas, Takeda, Pfizer, Teiji,n, Asahi-kasei, YL Biologics, Sanofi, Janssen, Eli Lilly and Company, GlaxoSmithKline, R. Klar Employee of: Quintiles IMS Holdings, Inc., L. Xie Employee of: Eli Lilly and Company, G. Meszaros Employee of: Eli Lilly and Company, T. Ishii Employee of: Eli Lilly and Company, M. Casillas Employee of: Eli Lilly and Company, R. Ortmann Employee of: Eli Lilly and Company, P. Emery Consultant for: Pfizer, MSD, Abbvie, BMS, UCB, Roche, Novartis, Samsung, Sandoz, Eli Lilly and Company

DOI: 10.1136/annrheumdis-2017-eular.1324

\section{FRI0088 SYNOVIAL PATHOBIOLOGY CORRELATES WITH DIAGNOSTIC SUBGROUPS IN EARLY INFLAMMATORY ARTHRITIS: RESULTS FROM THE PATHOBIOLOGY OF EARLY ARTHRITIS COHORT (PEAC)}

G. Lliso-Ribera ${ }^{1}$, F. Humby ${ }^{1}$, S. Kelly ${ }^{1}$, M. Bombardieri ${ }^{1}$, M. Lewis ${ }^{1}$, R. Hands ${ }^{1}$, V. Rocher ${ }^{1}$, F. Bene ${ }^{1}$, A. Nerviani ${ }^{1}$, C. Buckely ${ }^{2}$, P. Taylor ${ }^{3}$, I. Mclnnes ${ }^{4}$,

C. Pitzalis ${ }^{1}{ }^{1}$ Experimental Medicine and Rheumatology, Queen Mary University London, London; ${ }^{2}$ Centre for Translational Inflammation Research, University of Birmingham, Birmingham; ${ }^{3}$ Kennedy Institute of Rheumatology, University of Oxford, Oxford; ${ }^{4}$ Experimental Medicine and Rheumatology, University of Glasgow, Glasgow, United Kingdom

Background: Application of the 2010 ACR/EULAR Criteria for RA to early inflammatory arthritis cohorts permits an enhanced sensitivity for diagnosis compared to the historic 1987 ACR criteria but risks loss of diagnostic specificity. Heterogeneity in RA synovial pathobiology is well recognised with differences in qualitative and quantitative degree of immune cell infiltration, whether such heterogeneity correlates with classification criteria in early inflammatory arthritis is unknown, offering the potential to refine early diagnostic criteria.
Objectives: The aim of this study was to examine in a cohort of therapy naïve, early inflammatory arthritis patients whether synovial immune cell infiltration differed significantly between diagnostic categories of early inflammatory arthritis (ACR/EULAR 2010 vs ACR 1987 vs undifferentiated).

Methods: A total of 200 consecutive DMARD naïve early arthritis patients (disease duration $<1$ year) recruited as part of the multicentre PEAC study at Barts Health NHS Trust were categorised according to the following criteria: i. RA 1987 ACR, ii. RA 2010 ACR/EULAR, and iii. Undifferentiated Arthritis (UA). All patients underwent a baseline synovial biopsy of a clinically active joint along with collection of demographic data. Following H\&E staining, degree of synovitis was assessed. Sections underwent immumohistochemical staining and semi-quantitative scoring (0-4) to determine the degree of CD20+Bcells, CD3+T cells, CD68+ lining (I) and sublining (sl) macrophage and CD138+ plasma cell infiltration. Sections were categorised into three pathotypes: (i) Fibroid: (CD68 $\mathrm{SL}<2$ and or CD3, CD20, CD138<1), (ii) Myeloid: (CD68SL $>2, \mathrm{CD} 20<1$ and or CD3 $>1$ ) and (iii) Lymphoid: (grade 2-3 CD20+ aggregates, CD20>2).

Results: $166 / 200$ samples were suitable for analysis. 115 patients were classified as RA1987, 16 patients as RA 2010 ACR/EULAR and 35 as UA. $80 \%$ of synovial samples were collected from small joints (wrist, MCP, PIP). Although there were no significant differences in disease duration between diagnostic subgroups, patients classified as RA1987 criteria had significantly higher levels of CRP, tender and swollen joints, DAS28 and sero positivity for ACPA and RF. When patients were stratified into pathotypes, a numerically higher proportion of patients within the RA1987 group were categorised as lymphoid. Further, patients within the RA 1987 group had a significantly higher synovitis score and degree of immune cell infiltration.

\begin{tabular}{lcccc}
\hline N=166 & RA1987 (115) & RA2010 (16) & UA (35) & P value \\
\hline Fibroid 47 (\%) & $27(23.5 \%)$ & $6(37.5 \%)$ & $14(40 \%)$ & \\
Myeloid 57 (\%) & $38(33 \%)$ & $5(31.2 \%)$ & $14(40 \%)$ & 0.10 \\
Lymphoid 62 (\%) & $50(43.5 \%)$ & $5(31.2 \%)$ & $7(20 \%)$ & \\
CD3 T cells & 3.19 & 1.21 & 0.60 & $<0.001$ \\
CD20 B cells & 2.88 & 0.80 & 0.75 & $<0.05$ \\
CD68L macrophages & 3.60 & 1.86 & 1.34 & $<0.001$ \\
CD68SL macrophages & 3.60 & 2.18 & 1.79 & $<0.05$ \\
CD138 Plasma Cells & 2.85 & 1.06 & 0.73 & $<0.05$ \\
Synovitis Score & 6.17 & 3.26 & 3.24 & $<0.001$ \\
\hline
\end{tabular}

Conclusions: Stratifying patients according to baseline clinical diagnosis translates into differences in synovial pathobiology. The capacity to refine early clinical classification criteria through application of synovial pathobiological markers offers the potential to predict disease outcome and stratify therapeutic intervention. Disclosure of Interest: None declared

DOI: 10.1136/annrheumdis-2017-eular.2927

\section{FRI0089 EFFECT OF STARTING DOSE OF BARICITINIB IN ACHIEVING SUSTAINED LOW DISEASE ACTIVITY}

J.R. Curtis ${ }^{1}$, A. Kavanaugh ${ }^{2}$, D. van der Heijde ${ }^{3}$, D. Muram ${ }^{4}$, J. Alam ${ }^{4}$, S. Beattie ${ }^{4}$, J.S. Smolen ${ }^{5}$. ${ }^{1}$ Univ of Alabama at Birmingham, Birmingham; ${ }^{2}$ UC San Diego School of Medicine, la Jolla, United States; ${ }^{3}$ Leiden University Medical Centre, Leiden, Netherlands; ${ }^{4}$ Eli Lilly and Company, Indianapolis, United States; ${ }^{5}$ Medical University of Vienna, Vienna, Austria

Background: In Phase 3 studies, baricitinib (bari) treatment with 2 different doses (2 $\mathrm{mg}$ and $4 \mathrm{mg}$ once daily) demonstrated significant improvements across multiple measures of disease activity in patients (pts) with active RA and an inadequate response (IR) to conventional synthetic (cs) DMARDs (RA-BUILD ${ }^{1}$ ) or biologic (b) DMARDs (RA-BEACON²).

Objectives: To determine the effect of starting dose of bari on achieving and sustaining low disease activity (LDA).

Methods: RA-BUILD and RA-BEACON trials were 24 week (wk), placebo (PBO) controlled studies. Pts completing the studies on bari treatment could enter a long-term extension (LTE) study, RA-BEYOND, continuing blinded treatment with the same dose, while pts on PBO switched to bari $4 \mathrm{mg}$. This post hoc analysis assessed disease activity in pts who achieved CDAl $\leq 10$ at $\geq 1$ visit (LDA) or at $\geq 2$ consecutive visits (sustained LDA) within the originating study (24 wks) and continued into the LTE. The length of time required by pts to achieve LDA was determined by the incidence rate (percent pts responding per month) for each group.

Results: Treatment with bari $2 \mathrm{mg}$ and $4 \mathrm{mg}$, when compared to PBO, resulted in higher rates of LDA and sustained LDA, as well as higher incidence rates (shorter time to achieve LDA/sustained LDA) within 24 wks of each originating study. Across studies, treatment with bari $4 \mathrm{mg}$ demonstrated higher incidence rates when compared to bari $2 \mathrm{mg}$, both in achieving LDA and sustained LDA, indicating that these pts reached the desired LDA state faster. Incidence rates were lower in all treatment groups in bDMARD-IR pts compared with csDMARD-IR pts.

Conclusions: The most robust benefit in terms of achieving LDA and sustained LDA was observed with bari $4 \mathrm{mg}$ treatment, which required shorter time to response, than treatment with $2 \mathrm{mg}$. This was observed in both the short (24 wks) and in the long-term in pts with IR to csDMARDs or bDMARDs.

References:

[1] Dougados M et al. Ann Rheum Dis 2017; 76(1):88-95. 